\title{
The Influence of Heat Treatment on Mechanical and Corrosion Properties of Wrought Aluminium Alloys 2024 and 6064
}

Tomáš Kovalč́́k ${ }^{1}$, Jan Stouliil ${ }^{1}$, Peter Sláma ${ }^{2}$, Dalibor Vojtěch ${ }^{1}$

${ }^{1}$ Department of Metals and Corrosion Engineering, Institute of Chemical Technology in Prague, Prague 166 28, Czech Republic.Email: t.kovalcik@email.cz, stoulilj@vscht.cz,vojtechd@vscht.cz

${ }^{2}$ COMTES FHT, a. s., Průmyslová 995, 33441 Dobřany, Czech Republic. Email: pslama@comtesfht.cz

This article deals with the influence of the alloy temper during heat treatment on mechanical and corrosion properties of aluminium alloys 2024 ( $\mathrm{Al}-\mathrm{Cu}-\mathrm{Mg}$ ) and 6064 (Al-Mg-Si). For the experiment initial alloy tempers 2024T351 and 6064-T8 were heat treated to three conditions - underaged, peak aged (T6) and overaged - to simulate the circumstances during the manufacturing process. Structure of all conditions and tempers was observed. The mechanical properties - hardness, yield strength, ultimate strength and elongation - and corrosion properties maximum depth of corrosion attack peneration and corrosion rate in Audi immersion test for automotive industry (internal standard PV 11 13) - were measured. Structures of investigated alloy show evidence of intermediate phases arrangement in the direction of plastic deformation and they do not change during heat treatment. The lowest hardness, yield strength and ultimate strength have the underaged samples, the highest hardness, yield strength and ultimate strength have peak aged (2024) or initial samples (6064). Elongation decreases with ageing time or ageing temperature. In case of alloy 2024 corrosion rate and maximum depth of corrosion attack penetration increase with ageing time or temperature, in case of alloy 6064 corrosion rate increases with increasing ageing time or temperature while maximum depth of corrosion attack penetration decreases. Both alloys are attacked by intergranular corrosion with initiating surface pits.

Keywords: Aluminium alloys, heat treatment, precipitatiton hardening, corrosion and mechanical properties.

\section{References}

[1] WANG Z.; LI H.; MIAO F.; SUN W.; FANG B.; SONG R.; ZHENG Z. (2014). Improving the intergranular corrosion resistence without strength loss by two-step aging treatment. Materials and Engineering A, Vol. 590, p. $267-273$.

[2] MINODA T.; YOSHIDA H. (2002). Effect of grain boundary characteristics on intergranular corrosion resistance of 6061 aluminium alloy extrusion. Metallurgical and Material Transactions A, Vol. 33A, p. $2891-2898$.

[3] CAMPBELL, F. C. (2006). Manufacturing technology for aerospace structural materials. Elsevier, ISBN 978-185617-495-4.

[4] POLMEAR, I. J. (2005). Light alloys - From traditional alloys to nanocrystals (4 ${ }^{\text {th }}$ ed.). Elsevier. ISBN 978-07506-6371-7

[5] VARGEL, CH. (2004). Corrosion of aluminium. Elsevier. ISBN 978-0-08-044495-6

[6] HATCH, J. E. (1984). Aluminium: Properties and physical metallurgy. ASM International. ISBN 978-0-87170176-3

[7] GHOSH, K. S.; HILAL, M.; BOSE, S. (2013). Corrosion behaviour of of $2024 \mathrm{Al}-\mathrm{Cu}-\mathrm{Mg}$ alloy of various tempers. Transactions of Nonferrous Metals Society of China. Vol. 23, p. 3215 - 3227.

[8] CAMPBELL, F. C. (2008). Elements of Metallurgy and Engineering Alloys. ASM International. ISBN 978-087170-867-0

[9] EBOUL, M. C.; BAROUX, B. (2011). Metallurgical aspects of corrosion resistance of aluminium alloys. Materials and Corrosion, Vol. 62, No. 3, p. $215-233$.

[10] SCAMANS, G. M.; BIRBILIS, N.; BUCHHEIT, R. G. (2010). Shreir's corrosion. Vol. 3, p. $1974-2010$.

[11] STOULIL, J. (2012). Exfoliace karabiny v prostředí krasové jeskyně. Koroze a ochrana materiálu. Vol. 56, No. 1, p. $25-30$.

[12] BAJCURA, M. (2011). Korozní odolnost tažených tyčí ze slitiny EN AW 2011. Strojirenská technologie. Vol. 11, No. 4 , p. $2-6$.

[13] ECKERMANN, F.; SUTER T.; UGGOWITZER P. J.; AFSETH A.; SCHMUTZ P. (2008). Investigation of the exfoliation-like attack mechanism in relation to Al-Mg-Si alloy microstructure. Corrosion Science, Vol. 50, p. 2085 - 2093. 
[14] LARSEN, M. H.; WALMSLEY J. CH.; LUNDER, O.; MATHIESEN, R. H.; NISANCIOGLU K. (2008). Intergranular corrosion of copper-containing AA6XXX AlMgSi aluminium alloys. Journal of Electrochemical Society, Vol. 155, No. 11, p. C550 - C556.

[15] HAIDEMENOPOULOS, G. N.; HASSIOTIS N.; PAPAPOLYMEROU G.; BONTOZOGLOU, V. (1998). Hydrogen absorption into aluminium alloy 2024-T3 during exfoliation and alternate immersion testing. Corrosion, Vol. 54, No. 1, p. $73-78$

[16] LUO, C.; ZHOU, X.; THOMPSON, G. E.; HUGHES, A. E. (2012). Observations of intergranular corrosion in AA2024-T351: The influence of stored energy. Corrsoion Science, Vol. 61, p. 35 - 44.

Copyright (C) 2015. Published by Manufacturing Technology. All rights reserved. 